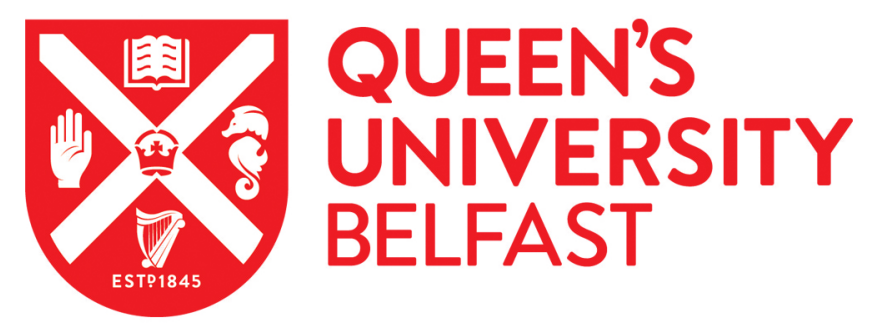

\title{
A Bridge Too Far? Attacks against Cultural Property used as Military Objectives as War Crimes: The Prlić et al. case and the Mostar Bridge
}

Moffett, L. (2020). A Bridge Too Far? Attacks against Cultural Property used as Military Objectives as War Crimes: The Prlić et al. case and the Mostar Bridge. International Criminal Law Review , 20(2), $214-250$. https://doi.org/10.1163/15718123-02002003, https://doi.org/10.1163/15718123-02002003

Published in:

International Criminal Law Review

Document Version:

Peer reviewed version

Queen's University Belfast - Research Portal:

Link to publication record in Queen's University Belfast Research Portal

Publisher rights

Copyright 2020 Brill Academic Publishers. This work is made available online in accordance with the publisher's policies. Please refer to any applicable terms of use of the publisher.

\section{General rights}

Copyright for the publications made accessible via the Queen's University Belfast Research Portal is retained by the author(s) and / or other copyright owners and it is a condition of accessing these publications that users recognise and abide by the legal requirements associated with these rights.

Take down policy

The Research Portal is Queen's institutional repository that provides access to Queen's research output. Every effort has been made to ensure that content in the Research Portal does not infringe any person's rights, or applicable UK laws. If you discover content in the Research Portal that you believe breaches copyright or violates any law, please contact openaccess@qub.ac.uk. 


\title{
A Bridge Too Far? Attacks against Cultural Property used as Military Objectives as War Crimes: The Prlić et al. case and the Mostar Bridge
}

Luke Moffett

\begin{abstract}
The destruction of the cultural property in conflict zones around the world has captured international attention on the need to prevent its destruction and prosecute those responsible. This article examines the current legal protection and international criminal framework on the criminalisation of the destruction of cultural property and in particular the exception to such destruction amounting to a war crime where they have become military objectives. This article discusses the recent decision in the Prlic et al case involving the Mostar bridge, in light of its being justified to be attacked as a military objective. This article argues that considerations of proportionality are still required in such circumstances. This is vital to minimise the cost to communities and peoples whose cultural identity is bound up with such cultural objects. The article also suggests that the perfidious use of cultural property by parties to a conflict should be criminalised.
\end{abstract}

\section{Keywords}

cultural property; proportionality; ICTY: military necessity; military objective.

Throughout 8 November 1993, a Bosnian Croat (HVO) tank fired dozens of shells at the Mostar Bridge (Stari Most). ${ }^{1}$ By the following morning the last connecting blocks of the $16^{\text {th }}$ century bridge tumbled into the Neretva river below, severing the connections between Bosnian Muslim enclave on the western bank of the river from the rest of Mostar. For the Bosnian Croat army $(\mathrm{ABiH})$, the destruction of the bridge was a military success, cutting off supplies to the Bosnian army. However for the Bosnian Muslim population the loss of the Ottoman bridge represented their isolation and obliteration of their belonging in Mostar. The bridge was rebuilt in 2004 and is now designated a UNESCO World Heritage Site. Yet only in December 2017 at the International Criminal Tribunal for the former Yugoslavia was the legality of such

\footnotetext{
${ }^{1}$ International Criminal Tribunal for the former Yugoslavia, Prosecutor v. Jadranko Prlić, Bruno Stojić, Slobodan Praljak, Milivoj Petković, Valentin Ćorić and Berislav Pušić, Trial Chamber, Judgment, IT-04-74-T (D2544), 29 May 2013, Vol.2, para.1313. Thanks to James Gallen and Dug Cubie for their comments on an earlier draft of this article. The author is very grateful to the insightful and constructive comments received by the anonymous reviewer.
} 
destruction settled. Although the case was overshadowed by Slobodan Prajlak's suicide on hearing the confirmation of his conviction, the Appeals Chamber notably overturned the Trial Chamber's decision that the destruction of the bridge was a war crime. While cultural property is protected during war, its change to a military objective may be too far outside the protection of the law as a result of this decision to be considered a war crime. This article reflects on the difficulty of whether or not cultural property that has become a military objective amounts to a war crime, and more broadly about the role of international criminal law in informing the conduct of hostilities.

There is a range of international legal instruments on cultural property that spans international humanitarian law, international criminal law and international heritage law, which aim to preserve, protect, and in the case of misuse, damage or destruction, to prosecute those responsible. This reflects the international importance attached to cultural property that transcends the temporary and geographic dimensions of its location and people, to be of significant value in preserving civilization and edifices of humanity. Indeed such sentiments are identically reflected in the 1954 Hague Convention on Cultural Property and the Rome Statute of the International Criminal Court that 'all peoples are united by common bonds, their cultures pieced together in a shared heritage, and concerned that this delicate mosaic may be shattered at any time. ${ }^{2}$ That said, despite the plethora of international laws now in this area, during times of armed conflict cultural property continues to be targeted, misused or collaterally damaged by state and non-state actors, as can be seen by the activities of ISIS and Ansar Dine, as well as threats by the likes of Donald Trump and Iran.

This article explores the increasing criminalisation of the destruction of cultural property that is military used in times of armed conflict and critically reflects on international criminal law's jurisprudence on the exception to the rule with the legality of attacks on cultural property that become militarily objectives. As Jenks suggests international criminal law can play an important role in informing the practice and compliance with international humanitarian law by belligerents in times of conflict through enforcing social norms and morals. ${ }^{3}$ Although Cryer more realistically suggests that at best international criminal law can have an indirect effect

\footnotetext{
${ }^{2}$ Preamble, 1954 Hague Convention, and Preamble, Rome Statute.

${ }^{3}$ See Chris Jenks, 'Moral touchstone, not general deterrence: The role of international criminal justice in fostering compliance with international humanitarian law', 96 (895/896) International Review of the Red Cross (2014) 775-784.
} 
on belligerents' actions and compliance with international humanitarian law. ${ }^{4}$ Yet if international criminal law is to have a deterrent effect on belligerents, the law has to be certain and effective in denunciate wrongdoings and communicate the law to relevant actors. ${ }^{5}$ While the Prlić et al. case settles the legality of the destruction of the Mostar bridge, it flattens the complex relationship people have with cultural property and the intrinsic value in protecting such irreplaceable sites from obliteration in war.

This piece begins by outlining the protection of cultural property and international humanitarian law and its criminalisation under international criminal law. Drawing on Lostal's concern of the atomisation of rules of cultural property, ${ }^{6}$ as will be seen from the diverging jurisprudence at the ICTY and other international courts, this article is not suggesting a new treaty, but rather the application of proportionality in distinguishing what amount of destruction of cultural property as a military objective should be criminalised. This is apparent in the recent completion of the Prlic et al case, where the judges in both the Trial and Appeals Chamber disagreed on the issue, and is the focus of the second half of the article. This article is distinguished from Cotter's recent work on the Prlić et al case, which focuses on the issue of dual-use objects, ${ }^{7}$ by framing the case within the broader issue of striking the balance between culturally protected objects, military necessity and proportionality. While Petrovic has highlighted how the Prlić et al case miscategorised the charges, ${ }^{8}$ the final section of this article argues that greater consideration should be on the place of proportionality in determining military necessity, in particular the disproportionate destruction of militarily used cultural property, as well as the criminalisation of those who perfidiously use cultural property as military objectives. In addition this article suggests that state and non-state armed groups can be better educated and engaged on the protection of cultural property that can work to their tactical advantage, greater

\footnotetext{
${ }^{4}$ Robert Cryer, 'The role of international criminal prosecutions in increasing compliance with international humanitarian law in contemporary African conflicts', in H. Kreiger (ed.), Inducing Compliance with International Humanitarian Law Lessons from the African Great Lakes Region (Cambridge, Cambridge, 2015), 188-216.

${ }^{5}$ Cryer, ibid., pp. 205 and 209; see also Serge Brammertz, 'The Impact of Criminal Prosecutions on Compliance with IHL: Challenges and Perspectives on the Way Forward', 39(1) University of Western Australia Law Review (2015) 4-30, p. 24. For instance the Al-Mahdi case before the ICC. This case is only briefly discussed, as it does not involve cultural property that has become a military objective.

${ }^{6}$ See Marina Lostal, International Cultural Heritage Law in Armed Conflict (Cambridge University Press, Cambridge, 2017), p. 9.

${ }^{7}$ Maurice Cotter, 'Military Necessity, Proportionality and Dual-Use Objects at the ICTY: A Close Reading of the Prlic et al. Proceedings on the Destruction of the Old Bridge of Mostar', 23(2) Journal of Conflict and Security Law (2018) 283-305.

${ }^{8}$ Jadranka Petrovic, 'Miscategorisation of the Old Bridge of Mostar in the Prlic et al Case', 8(1) Journal of the Philosophy of International Law (2017) 1-23.
} 
compliance with international humanitarian law and as a result the preservation of such sites.

\section{The Protection of Cultural Property in Armed Conflict in Historical Context}

Cultural property has long been valued as the means to transmit identity, memory and culture across time through built heritage and intangible practices. ${ }^{9}$ However war has often been incongruous to cultural property that seeks to maintain the identity, memory or history of certain events or diverse peoples in a locale. The legal protection of such property is not new. The first Caliph, Abu Bakr Siddiq (632634AD), instructed his troops to not molest Christian or Jewish worshipers or their monasteries. ${ }^{10}$ The 697CE Irish Cáin Adomnáin ('Law of Innocents') prohibited attacks against clergy and churches, imposing substantial fines on those who damage such cultural property. ${ }^{11}$ Vattel noted in 1758 that 'For whatever cause a country be devastated, those buildings should be spared which are an honor to the human race and which do not add to the strength of the enemy, such as temples, tombs, public buildings, and all édifices of remarkable beauty.' ${ }^{12}$ At the time of developing naval bombardment, he further suggests that bombardment of towns should be limited to the 'ramparts' so as 'to spare the finest buildings' of a town. ${ }^{13}$

The first state practices and later international agreements emerged in the 1860s and the start of the twentieth century. The 1899 and 1907 Hague Conventions recognised that cultural property should be spared from damage or destruction during bombardment or sieges of fortified towns, provided they are not used at the same time for military purposes. ${ }^{14}$ This protection encompassed buildings dedicated to religion,

\footnotetext{
${ }^{9}$ Robert Bevan, The Destruction of Memory (Reaktion Books, 2016), p26.

${ }^{10}$ François Bugnion, The origins and development of the legal protection of cultural property in the event of armed conflict, Speech, Fiftieth anniversary of the 1954 Hague Convention for the Protection of Cultural Property in the Event of Armed Conflict. Geneva: ICRC, 2004, available at https://www.icrc.org/eng/resources/documents/article/other/65shtj.htm, accessed 5 March 2018.

${ }^{11}$ Colin Smith and James Gallen, 'Cáin Adomnáin and the Laws of War', Journal of the History of International Law 16(1) (2014), 63-81, p79.

${ }^{12}$ Emmerich de Vattel, Le droit des gens: ou, Principes de la loi naturelle, appliqués à la conduite et aux affaires des nations et des souverains, chapter 9, (Londres, 1758), paras.167-168.

${ }^{13}$ Ibid., para.172.

${ }^{14}$ Article 35, Lieber Code; Article 17, Brussels Declaration 'International Declaration concerning the Laws and Customs of War' of 27 August 1874; Articles 34 and 53, Oxford Manual of the Institute of International Law of 1880; Articles 27 and 56, Convention (II) with Respect to the Laws and Customs
} 
art, science or charitable purposes, and historic monuments, as well as hospitals and places where the sick and wounded are collected. In addition, the 'seizure of, destruction or wilful damage' to such buildings was prohibited with those who violated this states were obliged to subject such individuals to legal proceedings. ${ }^{15} \mathrm{It}$ is apparent that for over 100 years belligerents in international armed conflicts have been obliged to preserve, protect and prosecute the misuse, damage and destruction of cultural property.

Despite these provisions, the First World War witnessed horrendous human loss, but also irrevocable damage to cultural property. On the $25^{\text {th }}$ August 1914, German forces burnt down the historic library at the University of Louvain, destroying over 230,000 volumes of unique collections and medieval manuscripts and sacking the town, as part of reprisals against attacks by perceived perfidious Belgian civilians or franc-tireur. ${ }^{16}$ Three weeks later in Reims the $13^{\text {th }}$ Century Cathedral was targeted by Germany shelling on the grounds its towers were being used as a French military observation post. At the time the French war manual permitted such attacks under military necessity, and would only have been seen as wanton destruction if the observation post was no longer used. ${ }^{17}$ In the aftermath of the conflict, reparations were made to account for some of this destruction of cultural property, but no-one was ever prosecuted for these violations. ${ }^{18}$

In between the World Wars there was some efforts by states to promote greater protection of cultural property during conflict, such as the 1935 Roerich Pact. ${ }^{19}$ The Pact did increase protection for cultural property by obliging belligerents to 'respect and protect' cultural property and to extend such protection in peace and war, as well as to personnel who manage such buildings, but such protection ended if

of War on Land and its annex: Regulations concerning the Laws and Customs of War on Land. The Hague, 29 July 1899; Articles 27 and 56 Convention (IV) respecting the Laws and Customs of War on Land and its annex: Regulations concerning the Laws and Customs of War on Land. The Hague, 18 October 1907; and Article 5, Convention (IX) concerning Bombardment by Naval Forces in Time of War, The Hague, 18 October 1907.

${ }^{15}$ Article 56, 1899 and 1907 Conventions.

${ }^{16}$ Barbara Tuchman, The Guns of August, Penguin (2014 republished), pp.346-349.

17 The fact of the cathedral being used as an observation post was disputed by the French, and it seems unlikely that the French army which had numerous observation balloons in the area would put such a historic building at risk. See James W. Garner, The Destruction of the Cathedral of Reims and The German Defence Analyzed, International Law and the World War, Longmans, Green and Co., London (1920), p.441-446.

${ }^{18}$ Articles 245-247, Treaty of Versailles.

19 The proposed 1935 Roerich Pact was only signed by 10 American countries, with no buy-in by British, French or German forces. See Roger O'Keefe, The Protection of Cultural Property in Armed Conflict, (Cambridge, Cambridge, 2006), p51-52. 
they were used for military purposes. ${ }^{20}$ However, it was only signed by 11 Latin American nations and was quickly overshadowed by the Spanish civil war and the aerial bombardment of Guernica. ${ }^{21}$ In response the League of Nations drafted a convention on the protection of historic building and works of art during times of war. Yet, it was never passed in time before the outbreak of hostilities in the Second World War. $^{22}$

Notwithstanding the efforts of the Roerich Pact and the League of Nations, the Second World War witnessed mass destruction of cultural property through air warfare by both Allied and Axis forces, as well as the mass looting by Nazi and Soviet forces. ${ }^{23}$ In the aftermath of the Second World War the international community was again convulsed to provide greater legal protection to cultural property during armed conflict. The outcome was the 1954 Hague Convention and its first protocol. ${ }^{24}$ The drafters of the 1954 Convention believed that the 1907 Hague Regulations had been overly ambitious in seeking greater protection of a broad range of cultural property and as a result got too little protection when hostilities commenced. ${ }^{25}$ As a result, the 1954 Convention protects moveable and immoveable cultural property of 'great importance to the cultural heritage of every people', including monuments, archaeological sites, historic buildings, works of art and historic book collections. ${ }^{26}$ Accordingly, the Convention creates a higher threshold, intended to be a more measured and feasible approach by more narrowly defining property worth protecting in times of armed conflict. ${ }^{27}$ Some have distinguished this Convention as part of an emerging International Cultural Heritage Law that includes

\footnotetext{
${ }^{20}$ Articles 1 and 5, Treaty on the Protection of Artistic and Scientific Institutions and Historic Monuments (Roerich Pact), Washington, 15 April 1935.

${ }^{21}$ O'Keefe, supra note 19, p. 50.

22 O'Keefe, ibid., pp. 53-61.

${ }^{23}$ The Russians argued that such looting was legitimate reparations for the pillaging of cultural property in the years previous by Nazi forces. See Andrea Gattini, 'Restitution by Russia of Works of Art Removed from German Territory at the End of the Second World War', 7(1) European Journal of International Law (1996) 67-88.

${ }^{24}$ Convention for the Protection of Cultural Property in the Event of Armed Conflict with Regulations for the Execution of the Convention 1954.

${ }^{25}$ O'Keefe, supra note 19, p. 101.

${ }^{26}$ Article 1(a). Also protected are museums, archives and centers containing a large amount of cultural property. The first protocol 1954 aims to protect cultural property and to prevent its exportation in occupied territory.

${ }^{27}$ Ibid. Jiř́ Toman, Cultural Property in War: Improvement in Protection Commentary on the 1999 Second Protocol to the Hague Convention of 1954 for the Protection of Cultural Property in the Event of Armed Conflict, (UNESCO, Paris 2009), p50.
} 
intangible cultural heritage as separate from previous treaties, which is not protected under international humanitarian law. ${ }^{28}$

Beyond the protection of the 1954 Hague Convention, it has two protocols, the first on moveable (1954) and the second on non-international armed conflicts (1999). The Geneva Conventions are silent on the matter of cultural property. This is remedied in the two 1977 additional protocols, which both virtually share the same language on the protection of cultural property and defer to the 1954 Hague Convention. ${ }^{29}$ The protection of cultural property under international humanitarian law has been criticised for its inconsistency, with four main treaties that differ in what amounts to cultural property, the levels of protection, and states use of protective emblems (e.g. the different types of blue shield). ${ }^{30}$ While these conventions set out a number of obligations on the protection of cultural property including not subjecting them to reprisals ${ }^{31}$ or looting, ${ }^{32}$ this article concentrates on directing attacks against cultural property that are militarily used, but also outlines the rules on targeting military objects in the vicinity of cultural property.

\subsection{The Protection of Cultural Property and Military Necessity}

The only exception to damage or destruction of cultural property during armed conflict under 1954 Hague Convention is where 'military necessity imperatively requires such a waiver'. ${ }^{33}$ Military necessity is a purposively and strategically ambiguous concept, as stated in the Hostages case it,

'permits a belligerent, subject to the laws of war, to apply any amount and kind of force to compel the complete submission of the enemy with the least possible expenditure of time, life, and money. In general, it sanctions measures by an occupant necessary to protect the safety of his forces and to facilitate the success of his operations. ... The destruction of property to be lawful must be imperatively demanded by the necessities of war. Destruction as an end in itself is a violation of international law. There must be some reasonable connection between the destruction of property and the overcoming of the enemy forces.... It does not admit the wanton devastation of a district or

\footnotetext{
${ }^{28}$ See Lostal supra note 6; and Roger O'Keefe, 'Protection of Cultural Property', in A. Clapham and P. Gaeta (eds.), The Oxford Handbook of International Law in Armed Conflict, (OUP, Oxford, 2014), 492-520, p.509.

${ }^{29}$ AP II excludes the provision on the prohibition of reprisals.

${ }^{30}$ Louise Arimatsu and Mohbuba Choudhury, 'Protecting Cultural Property in Non-International Armed Conflicts: Syria and Iraq', 91 International Law Studies (2015), 641-698, p648; and Lostal supra note 6, p. 3 and 26.

${ }^{31}$ Article 4(4), 1954 Hague Convention; and Article 53(c), AP I.

${ }^{32}$ Article 4(3), 1954 Hague Convention; and Article 15(1)(e), Second Protocol.

${ }^{33}$ Article 4(2). This contrasts to the obligation not to pillage or loot cultural property, which is absolute.
} 
the willful infliction of suffering upon its inhabitants for the sake of suffering alone. 34

At a minimum military necessity is about economy of resources in waging war. Schwarzenberger suggests it is an extra legal justification for not complying with international humanitarian law. ${ }^{35}$ Whereas Pictet proposes it is a last resort where a party to the conflict faces the impossibility of compliance in the face of the circumstances. ${ }^{36}$ McCoubrey finds that between these two views military necessity operations as a suspension or exception of international humanitarian law. ${ }^{37}$ Military necessity is not simply a measure of commander discretion, but a 'limitation to unbridled barbarity' with proportionality as a 'fulcrum' to balance it with the principles of humanitarian law. ${ }^{38}$ Indeed Luban suggests that the Hostages formulation of military necessity neglects the civilian aspect in such calculations that is only recalibrated through considering proportionality. ${ }^{39}$ The inclusion of proportionality and the impact of an attack on civilians, not only speaks to civilian protection, but also to the success of the military cause in terms of being shaped by public opinion. ${ }^{40}$ This is recognised in the US Lieber Code, where military necessity is considered as 'those measures which are indispensable for securing the ends of the war, and which are lawful according to the modern law and usages of war', ${ }^{41}$ but notes that acts of hostility go beyond what is necessary and 'makes the return to peace unnecessarily difficult. ${ }^{42}$

One of the cardinal principles of international humanitarian law is the principle of distinction, in that combatants and civilians as well as civilian objects and military objectives should be distinguished. ${ }^{43}$ Military necessity is also distinct from military objectives, which outlined in Additional Protocol I pertains to those objects

\footnotetext{
${ }^{34}$ Hostage Case, United States v. List (Wilhelm) and ors, Trial Judgment, Case No 7, (1950) 11 TWC 1230, 19th February 1948, International Military Tribunal [IMT], 1253-1254. Cited at the ICTY in Dario Kordic and Mario Cerkez, Case No IT-95-14/2-A, 17 December 2004, Judgement, para.686.

${ }^{35}$ Georg Schwarzenberger, International Law, Vol. II: The Law of Armed Conflict, (Stevens, London, 1968), p. 4.

${ }^{36}$ Jean Pictet, Development and Principles of International Humanitarian Law, (Martinus Nijhoff, The Hague, 1985), p.88.

${ }^{37}$ Hilaire McCoubrey, 'The nature of the modern doctrine of military necessity', 30(1-4) Military Law and Law of War Review (1991), 215-252, p.220.

${ }^{38}$ Craig J. S. Forrest, 'The Doctrine of Military Necessity and the Protection of Cultural Property during Armed Conflicts', California Western International Law Journal 37(2) (2007) 177-219, p. 181.

${ }^{39}$ David Luban, 'Military Necessity and the Cultures of Military Law', 26 Leiden Journal of International Law (2013), 315-349, p.343-344.

${ }^{40} \mathrm{Ibid}$. p. 338-339.

${ }^{41}$ Article 14, Instructions for the Government of Armies of the United States in the Field (Lieber Code), 24 April 1863.

${ }^{42}$ Article 16.

${ }^{43}$ Article 48, AP I.
} 
which by their 'nature, location, purpose or use make an effective contribution to military action and whose total or partial destruction, capture or neutralization, in the circumstances ruling at the time, offers a definite military of advantage. ${ }^{44}$ Hayashi helpfully distinguishes these two issues as 'military necessity justifies the property's destruction, whereas the property's status as a military objective justifies attacks being directed against it. ${ }^{45}$ This distinction will be helpful when discussing the Prlić et al case further below.

In relation to cultural property while the principle of military necessity is invoked, drafts of different conventions and manuals on the subject have tried to provide it with more normative content. Yet such content can suffer from the ambiguity of military necessity, without providing a clear line to demarcate which actions are permissible and those that are wrongful. The waiver of imperative military necessity in the 1954 Hague Convention exhibits the compromise between the idealist and realist camps in the negotiation of the Convention, where the former wanted it to be deleted on humanitarian concerns to protect cultural property, and the latter wanted to ensure that such obligations would not be onerous, in that they 'must not curtail military operations to such an extent that they become impossible. ${ }^{46}$ As a result, the use of the waiver reflects a higher standard of military necessity that would be invoked in exceptional circumstances. The waiver thus allows attackers to damage or destroy cultural property that is being used by the enemy where there is no other feasible alternative, and similarly for defenders to use such property to defend themselves. What this means in effect is that objects are protected only in so far as the dictates of commanders' discretion, where there is no feasible alternative, rather than the consideration of proportionality. ${ }^{47}$ Military necessity here represents a more limited consideration of the humanitarian protection for cultural property in this regard. The waiver represents a sleight of hand to facilitate the realist perspective that some protection of cultural property by those willing to be bound by it is better than overreaching and achieve little or none at all.

\footnotetext{
${ }_{44}^{44}$ Article 52(2), AP I; and Nuclear Weapons Advisory Opinion [1996] ICJ Rep 226, para.78.

${ }^{45}$ Nobou Hayashi, 'Requirements of Military Necessity in International Humanitarian Law and International Criminal Law', 28 Boston University International Law Journal (2010) 39-140, p. 113.

${ }^{46}$ Toman supra note 27, pp.75-76.

${ }^{47}$ This is clarified in Article 6 of the Second Protocol. See Jean-Marie Henckaerts, 'New rules for the protection of cultural property in armed conflict', International Review of the Red Cross 81(835) (1999) 593-620, p. 601.
} 
In terms of practice, the UNESCO Military Manual stipulates that damage or destruction of cultural property by imperative military necessity will usually be 'exceptional', there is no feasible alternative and not on the basis of military convenience, reflecting Pictet's impossibility of compliance understanding of military necessity. As such, UNESCO suggest that 'military forces must give serious, concerted and imaginative thought to feasible alternative courses of military action before destroying or damaging cultural property under their control' ${ }^{48}$ Forrest also suggests that most rules of international humanitarian law do not make explicit reference to military necessity and so its inclusion with cultural property is intended to reflect a narrow set of circumstances where commanders need to justify 'the very act which the rule attempts to prevent. ${ }^{49}$ This is apparent in a review of military manuals in the ICRC Customary IHL Database, where there are multiple references to military necessity in conducting operations and attacks near or on cultural property that is used. ${ }^{50}$

The 1954 Hague Convention also provides a 'special protection' category that can be designated by States, in which they are obliged to refrain from any act of hostility against it or military objective in its environs, unless in 'exceptional cases of unavoidable military necessity, ${ }^{51}$ A commander of a division can only make the decision on the loss of immunity, due to its use for a military purpose, or higher, and where circumstances permit, the opposing party is to be given reasonable notice of the withdrawal of immunity. ${ }^{52}$ To date only 18 refugees and centres of cultural property have been registered, ${ }^{53}$ this is due to the challenges of ensuring that such refuges are not in the vicinity of likely strategic, industrial or military targets, such as the Abu Simbel being too close to the Aswan dam to be eligible. ${ }^{54}$ As such the special protection category indicates that greater protection can be impractical for states to guarantee in times of conflict.

\footnotetext{
${ }^{48}$ Protection of Cultural Property: Military Manual, UNESCO (2016), para.126.

${ }^{49}$ Forrest supra note 38, p. 193-194.

${ }^{50}$ Such as the Central African Republic's Le Droit de la Guerre, Fascicule No. 3: Formation pour l'obtention du Brevet d'Armes No. 1, du Brevet d'Armes No. 2 et le stage d'Officier de Police Judiciaire (OPJ) Ministère de la Défense, Forces Armées Centrafricaines (1999), Chapter III, section 2.; and France's Fiche de Synthèse sur les Règles Applicables dans les Conflits Armés, Note No. 431/DEF/EMA/OL.2/NP, Général de Corps d'Armée Voinot, 1992, s.2.4.

${ }^{51}$ Articles 8 and 9.

${ }_{52}^{52}$ Article 11(3).

${ }^{53}$ This includes nine centres in Mexico and six communes in the Netherlands. International Register of Cultural Property under Special Protection, UNESCO 23 July 2015.

${ }^{54}$ Lostal supra note 6, p.26-27.
} 
The difficulty of clarifying military necessity is contrasted to the Additional Protocols to the Geneva Conventions, which only permit attacks against military objectives. ${ }^{55}$ This move toward distinguishing attacks against cultural property that are military objectives from discretionary determinations of military necessity, was intended to reduce its subjectivity and ambiguity. ${ }^{56}$ The language of the Additional Protocols is in line with the 1899 and 1907 Hague Conventions, which spoke of belligerents taking 'all necessary steps' to spare cultural property and forbids occupation or attacks on such buildings, unless there are being used for military purposes. ${ }^{57}$ The Protocols also prohibit using such cultural property 'in support of the military effort', which in of itself this does not justify it being attacked. ${ }^{58}$ Instead the clarification of a military objective requires a higher threshold for attacks where such cultural property makes 'an effective contribution to military action' for the enemy, and whose total or partial destruction, capture or neutralisation 'in the circumstances ruling at the time, offers a definite military advantage' for the attacker. ${ }^{59}$ Although there is a balance to be struck here between military necessity and humanitarian principles, the protocols offer something more definite to guide such decisionmaking. ${ }^{60}$

In terms of military necessity the Protocol sets out that it can only be justified to 'direct an act of hostility' against cultural property where by its function a military objective and there is "no feasible alternative available to obtain a similar military advantage to that offered by directing an act of hostility against that objective' ${ }^{61}$ It is clear that this excludes forces using military necessity as a justification for occupying cultural property as a defensive position or for some other reason, such as a shelter in bad weather. The move to clarifying military necessity, which under the Convention was vague and open to abuse, brought the Convention into line with the language of AP I on what constitutes a military objective. ${ }^{62}$ This can be seen in the discussion on military necessity and military objectives in relation to historic bridges, as to whether as strategic objectives they could be pre-emptively targeted. Under the 1954

\footnotetext{
${ }^{55}$ Articles 52(2) and 53, AP I and Article 16, AP II.

56 Toman supra note 27, p111.

${ }^{57}$ Article 27. The Roerich Pact provided that such protection would only end where the cultural property was used for military purposes (Article 5).

${ }^{58}$ Commentaries AP I para.2079.

${ }^{59}$ Article 52(2), AP I.

${ }^{60}$ Henckaerts supra note 47, p601.

${ }^{61}$ Article 6(a). Such a decision has to be made by an officer in command of a battalion or larger.

${ }^{62}$ Toman supra note 27, p103-104.
} 
Convention such a historic bridge could justifiably be destroyed under 'imperative military necessity', but under the Second Protocol and the requirement of a military objective, such a bridge could only be destroyed where its 'use' as a military objective warrants its destruction. ${ }^{63}$ The ICTY has developed a similar position discussed further below.

The Second Protocol adds a third layer of protection of 'enhanced protection' that is 'cultural heritage of the greatest importance for humanity', it is 'protected by adequate domestic legal and administrative measures recognising its exceptional cultural and historic value and ensuring the highest level of protection', and is not used for military purposes or to shield military sites. ${ }^{64}$ While the Protocol provides immunity for cultural property under enhanced protection, such protection can be suspended or cancelled if it fails to meet the previous requirements or lost if it is used as a military objective. ${ }^{65}$

Although these provisions provide greater guidance to states and commanders in dealing with cultural property in armed conflict, so far only 72 states are parties to the Second Protocol. Only 12 sites are registered under enhanced protection. ${ }^{66}$ As Lostal laments these treaties with their specific protection regimes have contributed to the atomisation of protection, where states have signed up to varying obligations under different treaties, which creates an operational challenge for multinational forces. ${ }^{67}$ For instance, the United Kingdom only ratified the 1954 Hague Convention and its protocols in $2017,{ }^{68}$ and the US while signing the Additional Protocol I of the Geneva Conventions, is not a ratifying state party.

It is apparent that the evolution of rules on the protection of cultural property in armed conflict is increasingly trying to provide more certainty and guidance. Yet more law does not equal greater clarity or protection. There are now a myriad of cultural property conventions, not always ensuring consistent application given the principle of reciprocity. ${ }^{69}$ Moreover, the Hague Conventions and Protocols make

\footnotetext{
${ }^{63}$ Kevin Chamberlain, 'Military necessity under the 1999 Second Protocol', in N. van Woudenberg and L. Lijnzaad (eds.), Protecting Cultural Property in Armed Conflict, (Nijhoff, Leiden, 2010) 43-49, p. 46.

${ }^{64}$ Article 10. Lostal supra note 6, p. 34.

${ }^{65}$ Article 13(1).

${ }^{66}$ List of Cultural Property under Enhanced Protection, (UNESCO, Paris, 2017).

${ }^{67}$ Lostal supra note 6, p. 34.

${ }^{68}$ Cultural Property (Armed Conflicts) Act 2017, 23 February 2017. Similarly in Ireland the Protection of Cultural Property in the Event of Armed Conflict (Hague Convention) Act 2017.

${ }^{69}$ Lostal supra note 6, p. 1.
} 
reference to different types of military necessity - 'unavoidable', 'imperative' and 'exceptional' that do little to clarify the extent to which cultural property can be attacked when it is being used as a military objective. The scope and application of the protection of cultural property during times of armed conflict is further complicated through the jurisprudence of international criminal tribunals.

\section{Criminalising the Destruction of Cultural Property in Armed Conflict}

In the aftermath of the First World War the Belgians and French were keen to see German officers prosecuted for destruction of cultural property committed; however, the Leipzig trials failed to hold anyone account for these crimes. ${ }^{70}$ Only after the Second World War was Alfred Rosenberg convicted at the Nuremberg International Military Tribunal for his leading role in 'Einsatzstab Rosenberg' to plunder cultural property from occupied countries including collections from museums, galleries and libraries. Rosenberg was found guilty of plundering and persecuting the Jewish people in Europe as a war crime and crimes against humanity, of which he was sentenced to death. ${ }^{71}$ However there were no prosecutions for destruction of cultural property at the Nuremberg or Tokyo tribunals. The 1954 Hague Convention vaguely obligates state parties to criminalise breaches of the convention, the 1999 Second Protocol remedies this by more clearly stipulating what these breaches include. ${ }^{72}$ Added to this, Additional Protocol I to the Geneva Convention treats the extensive destruction of cultural property as a grave breach, unless they are being used in support of the military effort' ${ }^{73}$

It is apparent that international criminal law does not treat all cultural property homogenously, but with different shades of protection. The ICTY statute provided the first clear war crime of destruction of cultural property to include 'seizure of, destruction or wilful damage done to institutions dedicated to religion, charity and education, the arts and sciences, historic monuments and works of art and science'. ${ }^{74}$ While this follows the definition in the 1907 Hague Regulations, it also had a nexus

\footnotetext{
${ }^{70}$ See Roger O'Keefe, 'Cultural Heritage and International Criminal Law', in S. Jodoin and M. C. Segger, Sustainable Development, International Criminal Justice, and Treaty Implementation, (Cambridge, Cambridge, 2013), 120-150, p.123-124.

${ }^{71}$ Article 6(b), Nuremberg Charter 2194582 UNTS 279.

72 Article 28, 1954 Hague Convention. See Article 15 of the 1999 Second Protocol.

73 Article 85(3)(d).

${ }^{74}$ Article 3(d), ICTY Statute.
} 
element, in that the destruction was 'closely related' to the conflict. ${ }^{75}$ Under the Rome Statute of the International Criminal Court, the war crime of destruction of cultural property comprises of '[i]ntentionally directing attacks against buildings dedicated to religion, education, art, science or charitable purposes, historic monuments, hospitals and places where the sick and wounded are collected, provided they are not military objectives' ${ }^{76}$ The provision is the same for international and non-international armed conflicts. The incorporation of cultural property as a war crime has not been comprehensive in hybrid bodies. ${ }^{77}$ The ECCC Statute has a specific provision based on the 1954 Hague Convention for 'destruction of cultural property during armed conflict'. ${ }^{78}$ However, O'Keefe points out that this is based on the tenuous interpretation by experts that set up the ECCC on Article 28 of the 1954 Convention on states introducing penal sanctions, rather than atrocities committed by the Khmer Rouge against Buddhist pagodas and Cham mosques. ${ }^{79}$

Despite the criminalisation for the destruction of cultural property, international criminal justice mechanisms have struggled to dynamically capture the way in which cultural property is damaged, misused and destroyed as war crimes. Instead these tribunals rely on the Hague Regulations 1907, 1954 Convention and Additional Protocols to guide their reasoning, with little critical reflection on the scope of criminality in the damaging or destruction of cultural property. The ICC in its first case on the destruction of cultural property in Timbuktu against Ahmed Al Faqi Al Mahdi ended in a guilty plea, with little exploration of the scope of the war crime in contrast to the ICTY's jurisprudence. Beyond war crimes there has been creative approaches by judges to recognise destruction of cultural property as evidence of the dolus specialis of genocide (but not actus reus), and for persecution and inhumane and degrading treatment as crimes against humanity at the ICTY ${ }^{80}$ The rest of this section explores how the ICTY has defined the scope of cultural property, before

\footnotetext{
${ }^{75}$ ICTY, Prosecutor v Kunarac, Case No. IT-96-23\&IT-96-23/1-A, Appeals Chamber Judgment, 19 June 2002, para.55-58. See O'Keefe supra note 70, p.122-123.

${ }^{76}$ Articles 8(2)(b)(ix) and 8(2)(e)(iv).

77 The Statute of the Special Court for Sierra Leone is silent on cultural property. The statute of the Kosovo Specialist Chambers and Specialist Prosecutor's Office Article 14(1)(b)(ix) and (d)(iv), reflect the language of the Rome Statute, rather than the ICTY statute.

${ }^{78}$ Article 7.

${ }^{79}$ Roger O'Keefe, 'Protection of Cultural Property under International Criminal Law', Melbourne Journal of International Law 11 (2010), 339-392, p360; and Arimatsu and Choudhury supra note 30, p. 686.

${ }^{80}$ ICTY, Prosecutor v Krstic, Case No. IT-98-33-T, Trial Chamber Judgement, 2 August 2001, para.550; and Prlić et al, Trial Chamber, Judgement, para.1229.
} 
examining its jurisprudence on directing attacks against cultural property used for military purposes and the recent Prlić et al case.

\subsection{Defining Cultural Property for the Purposes of War Crimes}

The 1954 Hague Convention sets out a range of cultural property as comprising of the 'movable or immovable property of great importance to the cultural heritage of every people'. ${ }^{81}$ The use of the language of 'great importance' and 'every people' suggests heritage that goes beyond local significance to transcend borders by being of value to humanity at large. As outlined above this is the minimalist protection approach to ensure more effective protection of a narrow scope of cultural property in times of armed conflict. In contrast, the statutes of the ICTY and Rome Statute broadly refer to 'institutions dedicated to religion, charity and education, the arts and sciences, historic monuments and works of art and science. ${ }^{82}$ That said, as Petrovic points out culture itself is an indeterminate notion, that is not static, but constantly evolving, with the value of such objects changing over time. ${ }^{83}$

What amounts to cultural property has also been examined by the ICTY to include religious buildings, historic property, certain education facilities and UNESCO World Heritage sites. The Balkans conflict was replete with attacks against Muslim, Orthodox and Roman Catholic religious buildings. ${ }^{84}$ In Hadžihasanović and Kubura the Trial Chamber held that due to the specific inclusion in 1907 Hague Regulations and Article 3(d) ICTY Statute with religious buildings there is "no need to establish whether it represented the cultural heritage of a people. ${ }^{85}$ In addition, and to be followed by the ICC in terms of 'attack' the Trial Chamber in Hadžihasanović and Kubura damage or destruction of religious institutions does not need to be carried out during military action, i.e. heat of battle, but only needs to be 'closely linked to the hostilities'. ${ }^{86}$ The Chamber justified this approach on the grounds that religious buildings 'spiritual value' which goes 'beyond the scope of a single individual and have a communal dimension, the victim here must not be considered as an individual

\footnotetext{
${ }^{81}$ Article 1(1).

${ }^{82}$ Article 3(d), ICTY Statute, and Articles 8(2)(b)(ix) and 8(2)(e)(iv), Rome Statute.

${ }^{83}$ Jadranka Petrovic, The Old Bridge of Mostar and Increasing Respect for Cultural Property in Armed Conflict, Nijhoff (2013), p. 20.

${ }^{84}$ ICTY, Prosecutor v Brđanin, Case No. IT-99-36, Trial Chamber, Judgment, 1 September 2004, para.430.

${ }^{85}$ ICTY, Prosecutor v Hadžihasanović and Kubura, Case No. IT-01-47-T, Trial Chamber, Judgement, 15 March 2006, para.60.

${ }^{86}$ Ibid., para.62.
} 
but as a social group or community' that amounts to 'desecration' ${ }^{87}$ In addition the Chamber stated that the 'seriousness of the crime of destruction of or damage to institutions dedicated to religion must be ascertained on a case-by-case basis, and take much greater account of the spiritual value of the damaged or destroyed property than the material extent of the damage or destruction. ${ }^{88}$ As Frulli points out under the ICTY statute and its jurisprudence there is no distinction of gravity in whether a small mosque is damaged or shelling of the World Heritage site of the Old Town in Dubrovnik as to whether or not it falls under Article 3(d). ${ }^{89}$ This sits in contrast to Additional Protocol I, which distinguishes places of worship 'normally dedicated to civilian purposes', and Article 53 that refers to the protection of places of worship that 'constitute the cultural or spiritual heritages of peoples'.90

The ICTY has held that not all attacks on education buildings will amount to cultural property, though they can be considered as destruction of civilian property. This would follow the position in Hadžihasanović and Kubura, as the 1907 Hague Regulations and Article 3(d) of the ICTY Statute do not specifically mention educational institutions, but do stipulate religious buildings. ${ }^{91}$ In the Kordić and Čerkez case the Appeals Chamber overturned the Trial Chamber's judgment that recognised all education buildings as cultural property of 'great importance'. The Trial Chamber held that 'educational institutions are undoubtedly immovable property of great importance to the cultural heritage of peoples in that they are without exception centres of learning, arts, and sciences, with their valuable collections of books and works of arts and science. ${ }^{92}$ Instead the Appeals Chamber distinguished the two different types of protection afforded to civilian property and cultural property as well as certain cultural property of 'great importance' under the Hague Conventions and Additional Protocols to the Geneva Conventions as having special or enhanced protection. As the Appeals Chamber stated in relation to cultural property of 'great importance' encompasses those 'objects whose value transcends geographical

\footnotetext{
${ }^{87}$ Ibid, para. 63

88 Ibid.

${ }^{89}$ Micaela Frulli, 'The Criminalization of Offences against Cultural Heritage in Times of Armed Conflict: The Quest for Consistency', 22(1) The European Journal of International Law (2011) 203217, p.207.

${ }^{90}$ See Marina Lostal, 'The Meaning and Protection of 'Cultural Objects and Places of Worship' under the 1977 Additional Protocols', 59(3) Netherlands International Law Review (2012), 455-72.

${ }^{91}$ The Hague Regulations 1907 and Article 3(d) ICTY statute cover 'buildings dedicated to religion, art, science, or charitable purposes, historic monuments'.

${ }^{92}$ ICTY, Prosecutor $v$ Kordić and Čerkez, Case No. IT-95-14/2-T Judgment (Trial Chamber), 21 February 2001, para.360.
} 
boundaries, and which are unique in character and are intimately associated with the history and culture of a people. ${ }^{93}$ As such not all educational institutions, such as schools, would fall under the heading of cultural property of 'great importance' and have complete immunity from damage or destruction. ${ }^{94}$ In addition, the Appeals Chamber rejected that any and all religious buildings have special protection. ${ }^{95}$

Damage to World Heritage sites have also been prosecuted at the ICTY, such as in Jokić, where the defendant pled guilty for his role in shelling the Croatian city of Dubrovnik as a World Heritage site that resulted in damage to over 100 buildings in the Old Town. The Trial Chamber held that that attack was unlawful in ignoring the immunity for specially protected cultural property making it 'especially wrongful conduct', with Jokić convicted of 7 years. ${ }^{96}$ At the ICC, the destruction of the UNESCO World Heritage Site in Timbuktu firmly fell within the remit as an unjustified attack against cultural property amounting to a war crime. Perhaps missing from each of these World Heritage cases, is the lack of the cultural property being used as a military objective, which would place greater analysis on whether such an attack was legitimate, and whether such destruction was proportionate such as the bombardment of the Citadel in Aleppo or the Krak des Chevaliers as UNESCO sites in Syria, if they are ever prosecuted.

The divergent and at times inconsistent jurisprudence emerging from international criminal institutions reflects the fuzzy boundary that has arisen in international law in protecting cultural property that is between civilian property and a more 'cultural-value approach' that cultural objects of 'great importance' would fall under, such as World Heritage sites. ${ }^{97}$ As Brammertz et al. suggest the ICTY has created three headings of protection that cultural property can fall under: 'general civilian objects, cultural property defined as "institutions dedicated to religion, charity and education, the arts and sciences, historic monuments and works of art and science", and finally cultural property of 'great importance" in contrast to the two in international humanitarian law. ${ }^{98}$ This broad conception of cultural property and its criminalisation is evident in the Iraqi Special Tribunal, which convicted Hussein

\footnotetext{
${ }^{93}$ ICTY, Prosecutor v Kordić and Čerkez, Case No. IT-95-14/2-A, Judgment (Appeals Chamber), 17 December 2004, para.91.

${ }^{94}$ Ibid., para. 92 .

${ }^{95}$ Commentary on the Additional Protocols, p. 647, para. 2067.

${ }^{96}$ ICTY, Prosecutor v Miodrag Jokić, , Case No. IT-01-42-T, Judgment (Trial Chamber), 18 March 2004, para.53. See also Strugar, IT-01-42-T, para.232.

${ }^{97}$ See Frulli n.89.

${ }^{98}$ Brammertz et al. supra note 5, p.12.
} 
Rashid and Ali Hassan al-Majid for intentionally destroying 1,344 Kurdish schools and over 2,027 mosques, recognising them as cultural rather than civilian property, without any requirement to distinguish them being cultural property of 'great importance'. ${ }^{99}$ This would seem to diverge from the intentions of the drafters of the 1954 Hague Convention to more narrowly define cultural property to ensure its better protection in conflict. It remains uncertain in more recent conflicts around the world whether this narrow approach has been effective, as the conflict in Syria demonstrates. Nonetheless, it is clear that the protection regime of cultural property in international criminal law cherry-picks from Hague and Geneva Law, but has broad normative elements of the importance of cultural property to communities and peoples.

\subsection{Directing Attacks against Militarily Used Cultural Property}

There are limits in determining whether cultural property loses its protected status and becomes a military objective, in particular with military necessity and the proportionality of such anticipated destruction. Military commanders in planning attacks against used cultural property face a two stage test: distinguishing whether it is a military objective or not; and whether the attack is proportionate. ${ }^{100}$ The damage or destruction of cultural property under Article 3(d) of the ICTY statute as a war crime makes no reference to military necessity or military objective, ${ }^{101}$ reflecting in part of the language of the 1907 Hague Regulations IV. ${ }^{102}$ Despite the ambiguity the ICTY Trial Chamber in the Blaškić case held that the war crime of destruction of cultural property is made up of the following elements:

'The damage or destruction must have been committed intentionally to institutions which may clearly be identified as dedicated to religion or education and which were not being used for military purposes at the time of the acts. In addition, the institutions must not have been in the immediate vicinity of military objectives.' 103

\footnotetext{
${ }^{99}$ Under Article 13(b)(10), Statute of the Iraqi Special Tribunal. Prosecutor v Al Anfal, Trial Chamber, Iraqi High Tribunal, No 1/C Second/2006, 2007 June 24, and Appellate Chamber, 4 September 2007.

100 Jadranka Petrovic and Rebecca Hughes, 'The Syrian conflict and the use of cultural property for military purposes', in J. Petrovic (ed.), Accountability for Violations of International Humanitarian Law: Essays in Honour of Tim McCormack (Routledge, Abingdon, 2016) 136-176, p.161-162.

${ }^{101}$ ICTY, Prosecutor v Kunarac, Appeals Chamber, Judgment, para.55-58. See O'Keefe supra note 70, p.122-123.

${ }^{102}$ Article 27(1).

${ }^{103}$ ICTY, Prosecutor v Blaškić, Case No. IT-95-14-T, Trial Chamber, Judgment, 3 March 2000, para.185.
} 
With the first of this two stage test is determining whether the cultural property amounts to a military objective, it does not mean that the requirements of international humanitarian law end there. In Kordic the ICTY Trial Chamber found that "protection of whatever type will be lost if cultural property ... is used for military purpose'. ${ }^{104}$ This is based on Article 27 of the 1907 Hague Regulations and is a position that the ICTY has evolved. The Appeals Chamber in Brđanin held that,

'Determining whether destruction occurred pursuant to military necessity involves a determination of what constitutes a military objective. Article 52 of Additional Protocol I contains a widely acknowledged definition of military objectives as being limited to 'those objects which by their nature, location, purpose or use make an effective contribution to military action and whose total or partial destruction, capture or neutralisation, in the circumstances ruling at the time, offers a definite military advantage'. ${ }^{105}$

In subsequent decisions the tribunal held that the ability of commanders to target such an object only lasts as long as the cultural property is being used as a military objective. ${ }^{106}$ Though the two terms pertain to distinct concepts - military necessity as justifying conduct, and military objective designating permissible objectives to attack. ${ }^{107}$ As discussed above, the shift from the reliance on military necessity alone in international humanitarian law indicates a move from subjective discretion, to a more objective standard in decision making on targeting militarily used cultural property. Indeed Forrest suggests that it is the 'use' of cultural property is distinguished from nature, location and purpose. For instance, the decommissioned HMS Belfast in the River Thames in London could be viewed as a military objective due to its nature and purpose, despite now serving as a museum. ${ }^{108}$ Instead it is the 'use' of such cultural property as a military objective that permits it to be targeted. That said use, location, nature and purpose may all coincide in cultural property that is used, such as the 12th Century Krak des Chevaliers in Syria being used by opposition forces to the Assad regime before the were bombarded and pushed out of the fortification by the Syrian army. ${ }^{109}$

\footnotetext{
${ }^{104}$ ICTY, Prosecutor v. Kordić and Čerkez, TC Judgment IT-95-14/2-T 21 February 2001, para.362.

${ }^{105}$ ICTY, Prosecutor v Brđanin, Appeals Chamber Judgment, IT-99-36-A, 3 April 2007, para.337.

${ }^{106}$ ICTY, Prosecutor v Prlić et al, Vol.3, para.175. See Petrovic and Hughes supra note 100, p161.

${ }^{107}$ Article 52(2), AP I. Petrovic and Hughes ibid., p160.

${ }^{108}$ Article 1(f) in contrast to Articles 6 and 13, Second Protocol. See Forrest supra note 38, p212-213.

${ }^{109}$ Syria Crusader castle Krak des Chevaliers has war scars, BBC News 22 March 2014, available https://www.bbc.co.uk/news/world-middle-east-26696113
} 
The location of cultural property in the vicinity of a military objective by itself does not permit the targeting of cultural property, as it also requires precautions in attack to minimise or avoid incidental damage. ${ }^{110}$ In the Strugar case involving the shelling of the Old Town of Dubrovnik the Hague Regulations 1907 and Hague Convention 1954 "prohibit acts of hostility "directed" against cultural property, Article 3(d) of the Statute explicitly criminalises only those acts which result in damage to, or destruction of, such property. Therefore, a requisite element of the crime [...] is actual damage or destruction occurring as a result of an act directed against this property.' 111 The Chamber found that as there were no military objectives in the vicinity of the city, the question of proportionality and military necessity did not arise. ${ }^{12}$ The requirement of cultural property not being in the 'immediate vicinity of military objectives' was rejected by the Trial Chamber in the Naletilic and Martinović case as justifying the destruction of cultural property closely placed to military objectives. ${ }^{113}$ The Trial Chamber in the Strugar case reaffirmed this position that 'the use of cultural property and not its location that determines whether and when the cultural property would lose its protection.' ${ }^{114}$ However, the Chamber noted that in practice if a military objective is in the vicinity of a special protected cultural property it may be difficult to establish that the cultural object was being directly attacked. $^{115}$

O'Keefe suggests the ICTY's approach may be an oversimplification of IHL as 'if by its nature, location, purpose or use such property makes an effective contribution to military action and its total or partial destruction, capture or neutralisation, in the circumstances ruling at the time, offers a definite military advantage' ${ }^{116}$ This is not just in the cases of use, but also in location, such as obstructing a line of fire on a military objective would amount to passive or de facto use. ${ }^{117}$ This can be seen with the Rome Statute that only prohibits 'directing attacks' against protected objects that are not military objectives, ${ }^{118}$ reflecting the customary

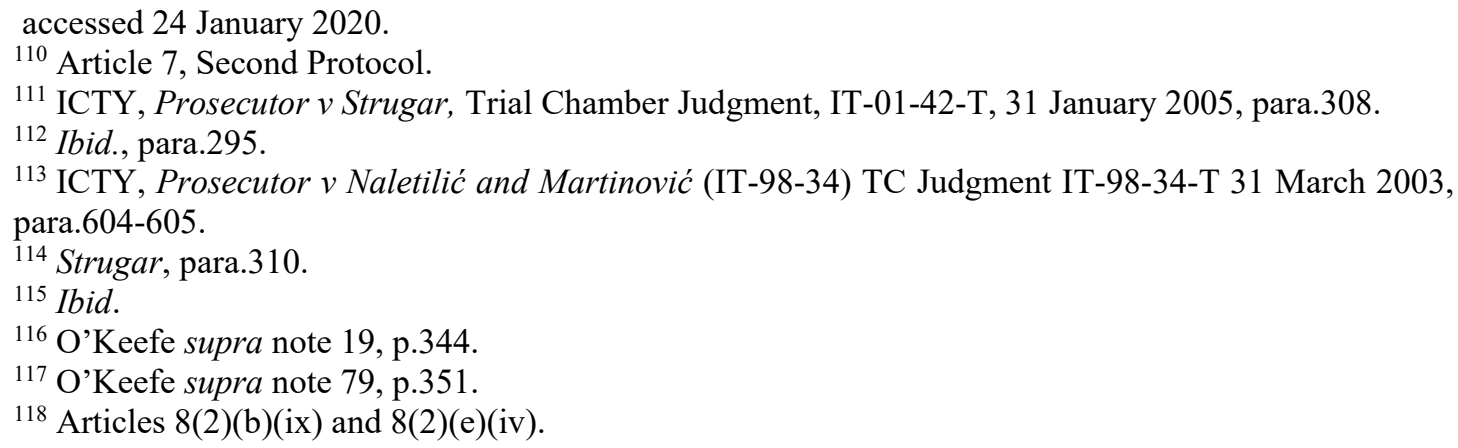


position that attacks can be carried out on military objectives near cultural property provided it is proportionate and precautions, where feasible, are taken. The tension between the customary position of cultural property protection in international law and the ICTY jurisprudence may indicate some teleological interpretation seeking greater protection for such objects in times of war. Indeed the destruction of cultural property during the Balkans conflict were not isolated events, damaged by stray shells and gunfire, but intentional and sectarian attacks to displace ethnic groups. Similarly in the Syrian conflict there are clear examples of the UNESCO World Heritage sites of Homs, Palmyra and Aleppo, where fighting in dense urban environments has inevitably led to mass destruction of cultural property and a devastating impact on the civilian population, that may not just be collateral damage, but intentional sectarian destruction. ${ }^{119}$ In such cases, whether or not international humanitarian law and international criminal law articulate a clear position on militarily used or use of cultural property may not matter to certain belligerents. That said, clarity can facilitate compliance for those who want to minimise the impact of the conflict on civilians or avoid prosecution in the future. As discussed in the last section such messages and information must be clearly disseminated and enforced.

A further distinction can be drawn between the ICTY and ICC in relation to damage or destruction carried out on cultural property outside of hostilities, but within the context of an international or non-international armed conflict. The language of Article 3(d) in the ICTY Statute makes no distinction on attacks against the enemy, such as would cover attacks on cultural property by ISIS against areas they occupied, such as the destruction of the Monumental Arch in Palmyra. This is in contrast to the ICC where the Rome Statute explicitly requires attacks. O'Keefe suggests that such wanton destruction of cultural property outside an attack could amount to the more unspecific crime of destroying enemy property. ${ }^{120}$ Nevertheless the ICC Prosecutor and Trial Chamber overlooked this issue when charging and convicting Mr Al Mahdi for the destruction of the World Heritage site in Timbuktu in 2012, which was an attempt to wipe out local Sufi practices, rather than an 'attack' as part of the armed conflict. The Trial Chamber in the Al Mahdi case noted that the jurisprudence of

\footnotetext{
${ }^{119}$ See Petrovic and Hughes supra note 100.

${ }^{120}$ O'Keefe supra note 79, p.347.
} 
ICTY was of 'limited guidance' to the ICC as the Rome Statute's language is on 'attacks', whereas the latter criminalises 'destruction or wilful damage'. ${ }^{121}$

O'Keefe finds that the Rome Statute more adequately reflects the customary international law position compared to the ICTY's interpretation. ${ }^{122}$ Yet the Rome Statute makes no reference to military necessity only allowing attacks were the cultural property has not become a military objective, drawing from the 1907 Hague Regulations IV. ${ }^{123}$ Bryon suggests that the Rome Statute's provisions provides a narrower defence than the Hague Regulations, by requiring a commander to assess whether attacking the cultural property will make an effective contribution to military action and its destruction would offer a definite military advantage. ${ }^{124}$ During the drafting of the Rome Statute the language of 'not being used at the time for military purposes' was included for a time. ${ }^{125}$ The final agreed upon draft of the Rome Statute makes reference to 'military objectives', intending to incorporate the language of Additional Protocol I than the Hague Regulations, it seems that rather than narrowing the defence to only military purposes, the use of 'military objective' would encompass location and nature to attack cultural property thereby widening the justification for attacking cultural property. ${ }^{126}$ That said if cultural property is identified as a military objective, proportionality requirements still apply on whether or not the anticipated scale of destruction of an objective can offer a definite military advantage. Despite these broader developments, there has been confusion and dissent in the Prlić et al case in determining whether the destruction of the Mostar bridge amounted to a war crime.

\subsection{The Destruction of the Mostar Bridge - the Prlić et al case}

In the Prlić et al case against Bosnian Croat military commanders, Slobdan Praljak and Milivoj Petković were charged with the destruction of the Mostar bridge. Both commanders were also charged with targeting Muslims in the Mostar area, including the destruction of 10 mosques in Mostar, the murder of Muslim civilians and Petković

\footnotetext{
${ }^{121}$ ICC, Prosecutor v Al Mahdi judgment, para.16. The Rome Statute still maintains the grave breach war crime of wanton destruction from the Geneva Conventions under 8(2)(a)(iv) that destruction of cultural property could also fall under.

122 O'Keefe supra note 19, p.345.

${ }^{123}$ Mahnoush H. Arsanjani, 'The Rome Statute of the International Criminal Court', 93(1) American Journal of International Law (1999), 33-34.

${ }^{124}$ Christine Byron, War Crimes and Crimes Against Humanity in the Rome Statute of the International Criminal Court Book, (Manchester University Press, Manchester, 2013), p.111.

${ }^{125}$ A/AC.249/1998/DP.11, p.14.

${ }^{126}$ Article 85(4)(d), AP I and Article 27(1), IV Hague Regulations.
} 
was charged with preventing humanitarian aid convoys from reaching the cut off Muslim population in East Mostar. ${ }^{127}$ This background of intentionally targeting the Muslim population in the Mostar area indicates that the destruction of the Mostar Bridge went simply beyond military necessity or to obtain a military advantage, but was part of a large plan to cause suffering to the Bosnian Muslims in Mostar.

In addressing the charge of the destruction of the Trial Chamber recognised that the bridge was essential to the Bosnian Army for its 'combat activities', being used to supply troop to the frontlines and with supplies, and at the time of the attack the bridge was a 'military target'. ${ }^{128}$ The Chamber examined whether or not intentionally shelling of the bridge by Croat HVO (Croatian Defence Council) forces that caused its collapse was required by military necessity or amounted to wilfully destroying cultural property. In determining this issue the Chamber took into account that $\mathrm{ABiH}$ (Army of the Republic of Bosnia and Herzegovina) forces often used the bridge as a supply route, the destruction of other bridges, and the 'significant psychological impact on the Muslim population in Mostar' in isolating them with the destruction of the bridge. ${ }^{129}$ The majority of the Chamber held that

'although the destruction of the Old Bridge by the HVO may have been justified by military necessity, the damage to the civilian population was indisputable and substantial. ... the impact on the Muslim civilian population of Mostar was disproportionate to the concrete and direct military advantage expected by the destruction of the Old Bridge. ... the destruction of the Old Bridge, in view of its immense cultural, historical and symbolic value for the Muslims in particular, was extensive. ... [and the HVO knew in targeting the bridge for destruction it would have the effect of] sapping the morale of the Muslim population of Mostar.' 130

Accordingly the Trial Chamber majority found that the destruction of the bridge amounted to the war crime of wanton destruction of cities, towns or villages, or devastation not justified by military necessity. ${ }^{131}$ Although the crime of destruction of cultural property was not directly charged in this case, it is the cultural and 'symbolic'132 importance such a bridge had for the Muslim population in Mostar that increased the weight of such value in its destruction in terms of proportionality. This 'nebulous' inclusion of the issue of psychological impact on the civilian population is

\footnotetext{
${ }^{127}$ ICTY, Prosecutor v. Jadranko Prlić, Bruno Stojić, Slobodan Praljak, Milivoj Petković, Valentin Ćorić and Berislav Pušić, Trial Chamber Judgment, IT-04-74-T, 19 May 2013, para.1579, Vol. III.

${ }^{128}$ Ibid., para.1582, Vol. II.

${ }^{129} \mathrm{Ibid}$. para.1354-1356.

${ }^{130}$ Ibid. para.1584-1586.

${ }^{131}$ Ibid. Vol. III, para. 1587.

${ }^{132}$ Ibid. Vol. II, para. 1356
} 
perhaps an indirect way for accountability for criminalising cultural property destruction, ${ }^{133}$ but also in proportionality considerations under international humanitarian law.

Judge Antonetti dissented from the Trial Chamber majority arguing that the destruction of the Stari Most was a legitimate military objective that could be directly targeted by $\mathrm{HVO}$ forces to cut off weapon and food supplies to the ABiH. ${ }^{134} \mathrm{In}$ addition at the time of the bombardment the Stari Most, while of cultural significance to the Muslim population, was not yet recognised as a UNESCO World Heritage site. In concluding Judge Antonetti found that the Old Bridge was a legitimate military objective that gave the HVO a 'definite military advantage by cutting off communications and the supply of food.' ${ }^{135}$ Furthermore, the Judge held that the principle of proportionality was inapplicable give the Stari Most was a military objective had to be destroyed and international humanitarian law does not recognise 'proportionate destruction'. Thus the analysis by the Trial Chamber in majority and dissent confuses military objective with military necessity, with proportionality not being considered as a fetter on the latter.

On Appeal the Chamber followed Judge Antonetti's dissent, deciding that as the Trial Chamber had found that the Mostar Bridge was a military objective its destruction was not wanton, but justified by military necessity. ${ }^{136}$ The majority of the Appeals Chamber did not engage in a substantive examination of proportionality, which forms part of Judge Pocar's dissent. His opinion diverges from the majority on the grounds that the rest of the Chamber had 'erroneously' conflated the concept of military objective with that of military necessity, neglected an examination of proportionality, and failed to consider the bridge as cultural property with broader protection under international humanitarian law. ${ }^{137}$ In relation to the first of these, the ICTY has often equated military necessity with a military objective, and as a result minimized analysis of both as distinct concepts - one relating to conduct and the other to distinguishing protected objects from military objectives. Through such an analysis, cultural property that becomes a military objective can be a consideration for

\footnotetext{
${ }^{133}$ Cotter supra note 7, p289.

${ }^{134}$ Prlić Vol. 6, IT-04-74-T, 19 May 2013, p320-326.

${ }^{135}$ Ibid. p326.

${ }^{136}$ Ibid. ara.411, Vol. I.

${ }^{137}$ Ibid. para.7, Vol. III.
} 
determining an attack if it is militarily necessary, ${ }^{138}$ but it is not conclusive without considering proportionality.

As Judge Pocar points out 'a disproportionate attack is per se unlawful and therefore cannot be justified by military necessity.' ${ }^{139}$ Indeed 'wanton destruction' involves excessive destruction as its key element of the crime, which requires assessing whether the harm caused was disproportionate to the military advantage gained. ${ }^{140}$ Judge Pocar also suggests that cultural property should be part of this calculation of proportionality, which requires consideration of other means and methods to secure the military advantage, such as 'blocking or destroying $\mathrm{ABiH}$ access' to the bridge. ${ }^{141}$ This line of reasoning draws from the differentiated language of the 1954 Hague Convention of 'imperative' military necessity that requires a high standard of military necessity in attacking civilian objects that have become military objectives. ${ }^{142}$ Again this reflects the distinct nature of cultural property from civilian objects, such as buildings identified as religiously important to a community, it is their 'spiritual value' that the law seeks to protect, which goes 'beyond the scope of a single individual and have a communal dimension' thereby requiring it to be given greater weight in the calculus of proportionality in planning an attack. ${ }^{143}$ Indeed the UK LOAC Manual considers attacks against cultural property as 'an aggravated form of attack on a civilian object, thus necessitating special care in operational planning.' ${ }^{144}$

While the Appeals Chamber finding is unsatisfactory when it comes to the protection of cultural property in times of armed conflict and conflates military necessity with military objective, ${ }^{145}$ it is unsurprising given the way in which the charge was framed. The problem lies in that the Mostar Bridge was not characterized as cultural property by the prosecution during the trial, as they had only charged the defendants with the destruction or willful damage to institutions dedicated to religion or educations, not historic monuments that the bridge would have fallen under Article

\footnotetext{
${ }^{138}$ ICTY, Prosecutor v Brđanin, Appeals Chamber Judgment, Case No. IT-99-36-A, 3 April 2007, para.337.

${ }^{139}$ Prlić para.9, Vol. III.

${ }^{140}$ Prlić, Vol.III, para.1584; and Judge Pocar para.11-11.

${ }^{141}$ Ibid. para.16,.

142 Ibid. para.15-16, ICTY, Prosecutor v. Strugar, Case No. IT-01-42-T, Appeals Chamber, Judgement, 17 July 2008, para. 277, refers to lex specialis of cultural property in contrast to civilian objects.

${ }^{143}$ Hadžihasanović and Kubura, Trial Judgment, para.63.

$144 \$ 5.25 .3$.

${ }^{145}$ Cotter supra note 7, p.296.
} 
3(d). ${ }^{146}$ The Trial Chamber noted that although Praljak was not charged or informed that the destruction of the Mostar Bridge fell under Count 21, the Chamber did not clearly distinguished the different legal requirements of the two crimes. Instead the Trial Chamber applied the law around Article 3(d) to the Count 20 charge on Article 3(b). ${ }^{147}$ Effectively Article 3(b) sets the standard of the justification for destruction for civilian centers as military necessity, whereas the specific provision for Article 3(d) is based on more specific requirements of the 1954 Hague Convention and the Additional Protocols that lean towards the requirement of military target and the test of proportionality with higher protective obligations on belligerents to avoid damage or destruction to cultural property. Reading the Trial Chamber's and Pocar's dissent in this light makes more sense of a conflation of count 20 against the defendants of wanton destruction not justified by military necessity (Article 3(b)) and count 21 on destruction to historic monuments (Article 3(d)). ${ }^{148}$ This suggests that the unsatisfactory outcome of the destruction of the bridge not being convicted as a war crime lies in the failure to properly characterize the destruction of the Mostar Bridge as cultural property by the prosecution, leaving the judges reaching for accountability. ${ }^{149}$

The divergence in views in the Trial and Appeals Chamber in the Prlić et al case reveals that judges themselves struggle to clarify the law on this issue, though this is unsurprising giving the fractured protection of cultural property in international humanitarian law. This decision contrasts to the earlier finding in the Strugar case where the two stage test was relied upon to find that the shelling of Dubrovnik amounted to a war crime as there were no military objectives in the vicinity of the city, and the question of proportionality and military necessity did not arise. ${ }^{150}$ Returning to Hayashi's distinction between military objectives and military necessity, while the bridge was a military objective justifying its attack, the consideration of military necessity to determine the justification of its destruction in light of proportionality helps to show its wanton destruction. ${ }^{151}$ This is apparent by the fact that the shelling of the bridge involved over 60 shells throughout the day until it

\footnotetext{
146 Para.1611, Vol. III TC.

${ }^{147}$ Para. 175-176, Vol. I.

${ }^{148}$ See Prlić, Second Amended Indictment, IT-04-74-T, 11 June 2008

149 The Appeals Chamber rejected the prosecution's arguments that the attack on the bridge was unlawful because it formed part of the HVO's campaign of terror. IT-04-74-A, fn1259.

${ }^{150}$ ICTY, Prosecutor v Strugar, Trial Chamber Judgment, Case No. IT-01-42-T, 31 January 2005, para.295.

${ }^{151}$ Hayashi supra note 45, p113.
} 
collapsed. Importantly for our analysis the destruction of the Mostar bridge did not have the loss of its cultural value at its heart, but 'merely evidence of another crime' of persecution and terror. ${ }^{152}$ Perhaps the protection of cultural property and its criminalisation needs a rethink.

\section{A New Approach?}

It is clear that the proliferation of law and its criminalisation has had little effect on compliance with international law on the protection of cultural property. It could be that the jurisprudence from the ICTY has been conflicting and the Appeals Chamber decision in Prlić et al missed an opportunity to clarify the law in this area. Greater certainty and clarity can be provided on cultural property that is militarily used. This section sums up some thoughts on moving forward with regard to cultural property protection in times of conflict and its prosecution for misuse and attacks.

In terms of prosecuting damage or destruction to cultural property, it is important to remember that international humanitarian law and international criminal law have diverging objectives. International humanitarian law is preventative, being directed at States (and non-state armed groups) in ensuring their forces respect and ensure compliance with the Laws of Armed Conflict, whereas international criminal law concentrates on individual criminal responsibility and thereby reactive. Not all violations of international humanitarian law fall within the scope of international criminal law, only grave breaches of international humanitarian law can amount to individual criminal responsibility, and to some extent coincide war crimes in international criminal law. However, war crimes in international criminal law require the contextual element to be satisfied - as such while this article discusses the prosecution of destruction of cultural property at international criminal courts and tribunals, there remains obligations in international humanitarian law for states to investigate and prosecute those responsible for such breaches. ${ }^{153}$ International criminal law does provide some leeway to commanders, that while analysing their decisions in hindsight, there is a requirement of reasonableness. ${ }^{154}$ Sivakumaran

\footnotetext{
${ }^{152}$ Timothy Waters, 'The persecution of stones: War crimes, law's autonomy and the co-optation of cultural heritage', Chicago Journal of International Law, 20(1) (2019), 62-97, p.95.

${ }^{153}$ Article 147, GC IV refers to the extensive destruction of property. The 1958 commentary refers to Article 53 on the prohibition of private and collective property, and the 1907 Hague Regulations on cultural property.

${ }^{154}$ Rogier Bartels, 'Discrepancies between International Humanitarian Law on the Battlefield and in the Courtroom: The Challenges of Applying International Humanitarian Law during International
} 
warns that a narrow approach of international criminal law to war crimes, risks narrowing the application of the broader protections of international humanitarian law. ${ }^{155}$ Moreover, there are evidential challenges, such as finding reliable witnesses and forensic access to damaged sites, in bringing a war crimes case. ${ }^{156}$

Perhaps an area that has seen little criminalisation is the misuse of cultural property by belligerents who use cultural property as a military objective. While it may be argued that this is a breach of international humanitarian law and not a war crime, the misuse of such cultural property is likely to increase its propensity to be attacked by the enemy. Such use could be seen as perfidious, as occupying cultural property can dissuade the enemy from attacking the building there by giving the defenders an unlawful advantage at the cost of international humanitarian law. ${ }^{157}$ Invoking Pictet's 'impossibility' of compliance for the use of military necessity in such instances where defending belligerents use cultural property would give too limited an account to the importance of cultural property and the necessary effects such destruction would have on the object and local populace.

This reflects a deeper issue with armed conflict and the laws of war where protection of cultural property objects, such as the Mostar bridge, can be intentionally misused to provoke the other side to attack it and commit destruction that may amount to a war crime. Thus the criminal intent and act, which can lead to the destruction of such cultural property, must weigh more heavily on those who put such cultural property in harms way. Yet there has yet to be a conviction of person for occupying cultural property and turning it into a military objective before any international criminal body. The Second Protocol to the 1954 Hague Convention only treats the occupation of enhanced protection cultural property as a serious violation of the protocol, whereas Dörmann suggests this is a grave breach. ${ }^{158}$ The Rome Statute of the ICC focusing on attacks, failed to characterise the occupation of cultural property as a war crime. ${ }^{159}$ There is a crime for using humans or other protected

Criminal Trials', in M. Matthee, B. Toebes and M. Brus (eds), Armed Conflict and International Law: In Search of the Human Face, (Asser Press, The Hague, 2013), 339-378, p.350.

155 Sandesh Sivakumaran, 'Re-envisaging the International Law of Internal Armed Conflict', 22(1) European Journal of International Law (2011), 219-264, p.220.

156 Bartels supra note 154, p350.

${ }^{157}$ Oliver Bangerter, 'Reasons why Armed Groups Choose to Respect International Humanitarian Law or not', 93 International Review of the Red Cross (2011) 882, 353-384, p.372.

158 Article 15(1)(b). See Knut Dörmann, Elements of War Crimes under the Rome Statute of the International Criminal Court: Sources and Commentary, Cambridge (2003), p.221.

159 Mireille Hector, 'Enhancing individual criminal responsibility for offences involving cultural property - the road to the Rome statute and the 1999 Second Protocol', in N. Van Woudenberg and L. 
persons to make a point, area or forces immune from military operations in international armed conflicts, and perhaps this could be a starting point if a crime was to be defined in terms of cultural property for any future codification of this crime. ${ }^{160}$

In re-examining the Prlić et al case, the Bosnian $\mathrm{ABiH}$ forces should not have used the Stari Most as a crossing point for supplying its forces, given the risk it would expose the bridge to HVO attack. However, this does not justify the disproportionate destruction by HVO forces on the bridge, which could have been more effectively achieved through more discriminate small arms fire. ${ }^{161}$ In the fighting around the Stari Most neither side complied with international humanitarian law, as a result civilians suffered. The Trial Chamber's effort to encompass this through countenance of the psychological impact on the civilian population to some extent represents this frustration that neither side cared for the impact of the conflict on civilians, at worst it represents the instrumentalisation of cultural property to arrive at a complex legal solution. ${ }^{162}$ The prosecution of those who intentionally target cultural property or disproportionately damage such cultural property, should be prosecuted, but so should those who misuse and occupy such property as a particularly grave breach. This would seem a more natural solution, rather than the complex and convoluted approach without sending a clear moral message on the wanton misuse of cultural property during conflict.

In terms of international humanitarian law, it is clear that proportionality is not clearly considered as a requirement for cultural property that is being militarily used. This neglects an important factor of military necessity that only such destruction as is necessary to achieve the military advantage is used, so as in the Lieber Code's language to avoid making 'return to peace unnecessarily difficult." 163 This taps into also more historical and cultural understands of the moral limits of warfare set out by Abu Bakr Siddiq and Vattel, on the higher onus on belligerents to avoid the loss of such cultural property in warfare, as it would necessarily create more animosity and perhaps reciprocity. While the law and jurisprudence in this area may not be clear, the practical implications of violating the sanctity of cultural property can

\footnotetext{
Lijnzaad (eds.), Protecting Cultural Property in Armed Conflict: An Insight into the 1999 Second Protocol to the Hague Convention of 1954 for the Protection of Cultural Property in the Event of Armed Conflict, (Brill, Leiden, 2014), 69-76, p.74.

${ }^{160}$ Article 8(2)(b)(xxiii), Rome Statute.

161 Petrovic supra note 69, p180.

162 Waters supra note 152, p.95.

163 Article 16.
} 
disproportionately affect civilian populations, which the majority in the Trial Chamber of the Prlić et al case were trying to recognise. Although the psychological effect of attacks may not be enough to make such destruction criminal in our current iteration of international criminal law or international humanitarian law, in practice it should give commanders pause for thought for determining the military necessity and proportionality of the destruction of cultural property which is being militarily used. Militarily used cultural property may be an exception to such sites being targeted, but it does not mean that proportionality does not apply nor the legality of destruction of such objects.

While the jurisprudence of the ICTY remains contradictory, in light of the purpose of international humanitarian law to minimise the consequences of armed conflict on civilians, it is possible to salvage some important principles. In particular in terms of military used cultural property a two-stage test of attacks should be considered: 1 . is it a military objective that permits it to be attack; and if so 2 . what are the proportionate means and methods to achieve the anticipated military advantage? Indeed the Second Protocol to the 1954 Hague Convention focuses on military advantage and objective rather than military necessity indicates the shift to engaging in a proportionality, by weighing military advantage against the potential damage or destruction of cultural property. ${ }^{164}$ The UK LOAC Manual in reference to cultural property where in the 'rare' cases it is 'essential' to use cultural property for military purposes, such as a 'historic bridge', 'only occur where there is no choice possible between the use of cultural property for military purposes and another feasible method for obtaining a similar military advantage. ${ }^{165}$ In this formulation of international humanitarian law we can better see the role of international criminal law, wherein attacks on militarily used cultural property which are not proportionate can potentially be war crimes provide other factors are satisfied. Additional Protocol I uses slightly different language for international humanitarian law for proportionality as 'excessive' in carrying out an attack, ${ }^{166}$ whereas grave breaches that can fall under the jurisdiction of international criminal law as 'extensive', suggesting there is a margin of appreciation in the scale of such damage that would suggest intentional destruction, i.e. more than

\footnotetext{
${ }^{164}$ Article 6(a), Second Protocol. Forrest supra note 38, p212.

165 The Joint Service Manual of the Law of Armed Conflict (2004), para.5.25.3.

166 Article 51(5)(b), AP I.
} 
superficial damage by small arms fire. ${ }^{167}$ As such, the Prlić et al case was a missed opportunity to provide clarity to international humanitarian law for cultural property that has become a military objective.

In determining proportionality it is not just about the number of cultural property objects that will be damaged, but more qualitative factors of the intrinsic value of the cultural property that risks being damaged or destroyed. ${ }^{168}$ Moreover, proportionality is considering the factors at the time of the operation; it is not an examination in hindsight, but information available to a commander in a short time frame with limited information before authorising an attack, ${ }^{169}$ so as not to discourage those acting in good faith. ${ }^{170}$ As such the two-stage test for attacking cultural property requires examination of whether or not the object is a military objective, and if so then whether the means and methods of such attack are proportionate. ${ }^{171}$

Considerations such as whether using high explosive shells is going to have on cultural property, whether small calibre fire would have the same effect, ${ }^{172}$ what extent is it being used as a military objective (sliding scale of 'extensive contribution' from a defensive position to enemy food cache), ${ }^{173}$ whether or not it is a World Heritage site or registered in the national cultural property list, and if there is other cultural property in the vicinity that are not used that risk being damaged by such an attack. It is apparent that bombardment in cities, whether using precision guided munitions or not, is likely to cause splash explosive damage to cultural property in the vicinity and likely civilians that always has to be a consideration in carrying out attacks in urban areas. There is some emerging practice that commanders should have the 'best possible intelligence' on protected sites such as cultural property and civilian population concentrations in assessing the impact of incidental damage. ${ }^{174}$

\footnotetext{
${ }^{167}$ Article 85(4)(d), AP I.

168 O'Keefe supra note 19, p219.

${ }^{169}$ Luke A. Whittemore, 'Proportionality Decision Making in Targeting: Heuristics, Cognitive Biases, and the Law', Harvard National Security Journal, 7, 577-636, p578.

${ }^{170}$ Robert Sloane, 'Puzzles of Proportion and the "Reasonable Military Commander": Reflections on the Law, Ethics, and Geopolitics of Proportionality', Harvard National Security Journal 6 (2015) p.333.

${ }^{171}$ Petrovic and Hughes supra note 100, p.162.

172 Patty Gerstenblith, 'The Destruction Of Cultural Heritage: A Crime Against Property Or A Crime Against People?', 15 The John Marshall Review of Intellectual Property Law (2016), 316-393, p.391.

${ }^{173}$ Brđanin (IT-99-36), para.596.

${ }^{174}$ See Isabel Robinson and Ellen Nohle, 'Proportionality and precautions in attack: The reverberating effects of using explosive weapons in populated areas', 98 International Review of the Red Cross (2016), 107-145, p.136.
} 
The Prlić et al case also raises the issue of whether the psychological impact of such an attack should be considered by commanders. This is probably a stretch too far for ordinary considerations of proportionality, as it would normally go beyond the physical harms that may impact on civilians in the area. Any sort of shelling or attack in a city is likely to cause psychological harm and distress to civilians. It could be argued that the community connection to cultural property, imbued with their collective history and identity that any attack on its edifice would cause communal psychological harm. A too inclusive approach that would include attacks against all militarily used cultural property would as disproportionate given the psychological impact, would result in little adherence and would be difficult for commanders to discern, given the local knowledge needed and the limits of the fog of war for foreign occupying or belligerent forces. It is perhaps better to capture this sentiment under other areas, such as belligerents being prohibited from using acts or threats of violence against civilians so as to spread terror, which targeting of cultural property may amount to where it is not militarily used. ${ }^{175}$

There is some emerging state practice to support this position, the Australian Commander's Guide stipulates that protection of cultural property may be lost if it is used for military purposes, but 'care must be taken to ensure that only reasonable force is used.' ${ }^{176}$ Other references to proportionality are made by manuals of Canada, ${ }^{177}$ France, ${ }^{178}$ and as part of the US ratification of the Hague Convention by the Senate. ${ }^{179}$ This does not reflect consistent and continuing practice, or opinio juris. ${ }^{180}$ However, it does indicate emerging understanding that the military objective standard by itself for cultural property is insufficient to ensure its protection, as it is not simply civilian property, but specially protected property given is unique nature and value to communities and peoples.

\footnotetext{
${ }^{175}$ Article 51(2), AP I. See ICTY, Prosecutor v. Stanislav Galić, Case No. IT-98-29-T, Trial Chamber, Judgment, 5 December 2003.

${ }^{176}$ Law of Armed Conflict: Commanders' Guide, Australian Defence Force Publication 37(1), 7 March $1994, \S 409$.

${ }^{177}$ Law of Armed Conflict Manual at the Operational and Tactical Level, Office of the Judge Advocate General (1999), para.69, and Rule 9(5), Canada's Code of Conduct for CF Personnel, Office of the Judge Advocate General, (2001).

${ }^{178}$ Fiche didactique relative au droit des conflits armés, Directive of the Ministry of Defence, 4 January 2000 , p5.

${ }^{179}$ Advice and Consent to Ratification of the 1954 Hague Convention for the Protection of Cultural Property, 2008, s.2(1).

${ }^{180}$ Legality of the Threat or Use of Nuclear Weapons, (Advisory Opinion), 1996 International Court of Justice Reports 226, 254, para.64
} 
Attention to the protection and preservation of cultural property should not be aimed at just state forces, but also non-state armed groups given the prevalence of non-international armed conflicts. Non-state armed groups can have a number of motivations for attacking and destroying cultural property, including ideological, strategic, demonstrate strength or economic incentives (such as looting). ${ }^{181}$ Nevertheless Lostal et al note that non-state armed groups attitudes towards cultural heritage are diverse, and they identify two trends of destructive and safeguarding. ${ }^{182}$ With the former of these trends the destruction carried out by IS or Ansar Dine demonstrate these groups ideological goals in rejecting other religions and the international community. Building and monuments can be 'ideologically saturated', politicised by how and why they are 'built, regarded and destroyed.' ${ }^{183}$ By destroying such cultural property it is a way for these groups to assert authority, project power and defy the world order. ${ }^{184}$ Certain armed groups have intentionally targeted cultural property of particular communities in order to weaken their resistance. ${ }^{185}$

As a final point perhaps a softer approach of 'safeguarding' may be conducive to ensuring protection of cultural property. Given cultural property is valued by certain communities, for forces using cultural property for military purposes can cause resentment and resistance amongst the civilian population that such valuable sites are not being respected. For instance the US use of the ninth century minaret in Samara as an observation post exposed it to insurgent gun and rocket fire, damaging its brickwork. ${ }^{186}$ Similarly the military occupation and destruction of mosques by the Khmer Rouge, caused the Cham Muslim minority in Cambodia to resist them, the only organised group that did so within the country. ${ }^{187}$ Protecting and respecting cultural property can be a 'force-multiplier' for belligerents, whereby not attacking or

\footnotetext{
${ }^{181}$ Johan Brosché, Mattias Legnér, Joakim Kreutz and Akram Ijla, 'Heritage under attack: motives for targeting cultural property during armed conflict', 23(3) International Journal of Heritage Studies, (2017), 248-260, p.249.

${ }_{182}$ Marina Lostal, Kristin Hausler, and Pascal Bongard, 'Armed Non-State Actors and Cultural Heritage in Armed Conflict', 24(4) International Journal of Cultural Property (2017), 407-427, p.411.

183 Bevan supra note 9, p.23.

${ }^{184}$ Lostal et al. supra note 182, p.413.

185 Alessandro Chechi, The Settlement of International Cultural Heritage Disputes, (OUP, Oxford, 2014), p.250.

${ }^{186}$ Frederik Rosén, NATO and Cultural Property: Embracing New Challenges in the Era of Identity Wars, (Nordic Center for Cultural Heritage and Armed Conflict (CHAC), Coepnhagen, 2017), p.26.

${ }^{187}$ See Ysa Osman, The Cham Rebellion: Survivors' Stories from the Villages, (Documentation Center of Cambodia, Phnom Penh 2006).
} 
placing military objectives in or around cultural property can make a positive contribution in winning over the hearts and minds of the local population. ${ }^{188}$

There is some emerging practice that belligerents avoid attacking cultural property, even where it is military used by the enemy. Avoiding an attack on such objects may not be about complying with international humanitarian law, but to maintain the support of the civilian population (or at least not to deteriorate it further). For instance on the offensive against IS in Mosul, Iraq, coalition forces avoided bombing the Al-Nuri mosque, despite it being used by IS and the location of Abu Bakr al-Baghdadi's famous declaration of the Caliphate in 2014. Similarly in Libya coalition forces destroyed a radar station position on top of an ancient Roman fortification at Rasaimergib, using precision munitions without damaging the cultural property. ${ }^{189}$ In Mali government forces decided against using an airstrike against an insurgent position beside the Djinguereber mosque in Timbuktu and instead used artillery to attack it from a side angle. ${ }^{190}$ This is not to suggest lawful compliance, but more likely policy choices due to practical and social disincentives to directly or indirectly damaging or destroying cultural property. ${ }^{191}$ This can be seen with US forces a few weeks later in Raqqa, Syria blowing up two $25 \mathrm{~m}$ holes in the historic $2,500 \mathrm{~m}$ wall around the city, justifying it as avoiding improvised explosive devices ISIS protecting collation forces and civilians as well as preserving integrity of the greatest portion of the wall'. ${ }^{192}$ Accordingly, there can be a range of means and ways to better protect cultural property from certainty in the law to improving tactical decisions. The normative and practical value in not targeting or using cultural property as a military objective have a long history that speaks to local and universal conceptions on the limits on warfare.

\section{Conclusion}

Cultural property objects are unique and often historical buildings that are closely connected to collective values and identities of communities, peoples or humanity.

\footnotetext{
${ }^{188}$ Peter G. Stone, 'A four-tier approach to the protection of cultural property in the event of armed conflict', 87(335), Antiquity, (2013), 166-177, p.170.

${ }^{189}$ UNESCO Military Manual, p.36.

190 Ibid., p37.

${ }^{191}$ Department of Defense, Law of War Manual , (Pentagon, Washington, DC, 2015), p. 185, online at https://info.publicintelligence.net/DoD-Law-of-War.pdf accessed 24 January 2020.

${ }^{192}$ Coalition Spokesman, Col. Ryan Dillon, SDF Breaches Old City of Raqqah, 4 July 2017, online at https://www.centcom.mil/MEDIA/PRESS-RELEASES/Press-ReleaseView/Article/1236906/sdf-breaches-old-city-of-raqqah/ Accessed 24 January 2020.
} 
Distinguishing them as simply protected or military objectives is no longer fit for purpose in increasing urban battlegrounds, where they can be used, even temporarily as military objectives. The destruction of cultural property has to be a consideration in proportionality in minimising the irreparable harm to such property in times of conflict, but without a normative understanding of the local and international value of such objects military necessity will be ill-informed and risk provoking further hostility amongst the local population. International humanitarian law is premised on minimising the human consequences of warfare on civilians and those hors de combat, more blood and bones rather than brick and stones. Yet cultural property objects are not detached from what is means to being human and finding belonging through place and objects. As Petrovic suggests that in times of armed conflict, people are concerned not only with their own survival, but their 'dignity, memory, heart and soul' that are imbued with cultural property for subsequent generations. ${ }^{193}$ Indeed the protection of cultural property has been part and parcel of law placing limitations on warfare from its inception, recognising the consequences of war need to be restrained from wiping out culture. Yet the law struggles to find the correct balance in clarity and compliance that can effectively protect cultural property on the battlefield, even where it is being misused.

The Mostar Bridge and the Prlić et al case encapsulate these struggles between protection of cultural property on the one hand and military necessity and realities of war on the other. More importantly the differing viewpoints in the Prlić et al case representing the lack of certainty even among international judges on the issue. It is apparent that cultural property, which is militarily used, still requires the consideration of proportionality. This is not to take a humanitarian only perspective on this issue, but to appreciate the symbiotic relationship between military necessity and the principle of humanity. ${ }^{194}$ Minimising or avoiding damage or destruction to cultural property can also be beneficial to belligerents, where winning hearts and minds of the civilian population can help reduce resistance against them. Moreover, there is need to prosecute those who misuse cultural property causing it to be attacked and to engage non-state armed groups on their obligations to protect such objects. Taking a step back the destruction of sites such as Palmyra and Sanaa, the failure to

\footnotetext{
${ }^{193}$ Petrovic supra note 69, p95.

194 Michael N. Schmitt, 'Military Necessity and Humanity in International Humanitarian Law: Preserving the Delicate Balance', 50(4) Virginia Journal of International Law (2010), 795-839, p.796.
} 
find new ways of communicating and forcing compliance with respect to cultural property will impoverish future generations. International humanitarian law plays an important role in limiting the excesses of armed conflict. Criminal trials are one way of enforcing it, but are imperfect forums for striking the correct balance between military necessity and the principle of humanity, which risk over-legalising such issues and disrespecting the practical application by military commanders in the field. ${ }^{195}$ Trials often take years to complete and, as in the Prlić et al case demonstrates, do not always result in accountability for all crimes.

Protecting cultural property needs to be a priority for states, non-state armed groups and international organisations so as to ensure that future generations can benefit from our shared past. The strength of humanity is through its diversity of communities and peoples that manifests through culture. International humanitarian law and international criminal law could better appreciate the value of cultural ties people and communities have by criminalising those who use cultural property as a military objective and perfidiously disrespect its protection as well as those who disproportionately attack such objectives. There have to be more proportional limits to destruction in warfare so as to maintain cultural property for posterity.

${ }^{195}$ Ibid. p839. 